\title{
Micrometrical Studies of Bronchi and Bronchiole in Prenatal Gaddi (Breed) Sheep Lung
}

\author{
Brij Vanita $^{1}{ }^{*}$, Rajesh Rajput $^{1}$, Virender Pathak $^{1}$, Varun Sankhyan ${ }^{2}$ and Ankaj Thakur ${ }^{3}$ \\ ${ }^{1}$ Department of Veterinary Anatomy, ${ }^{2}$ Department of Animal Genetics and Breeding, \\ ${ }^{3}$ Department of Livestock Farm Complex, DGCN College of Veterinary and Animal Sciences \\ CSK HPKV, Palampur-176062 (Himachal Pradesh), India
}

*Corresponding author

\section{A B S T R A C T}

The present study was conducted to investigate various micrometric parameters of bronchiole and bronchi in prenatal Gaddi sheep lung. A total of $n=18$ Gaddi sheep fetuses

\section{Keywords}

Bronchiole, Epithelium, Gaddi sheep, Prenatal lung, Micrometry

Article Info

Accepted:

15 March 2019

Available Online:

10 April 2019 were collected from various slaughter houses in and around Palampur town for one year. The prenatal lung samples were divided into three groups which included group-I (0-50 days of gestation), group-II (50-100 days of gestation) and group-III (100-150 days of gestation) based on their age in days. The overall diameter of bronchiole increased from group-I to group-III. However, the diameter of bronchi decreased significantly in right apical, left apical and left cardiac lobe but it increased significantly in right cardiac and left diaphragmatic lobe from group-II to group-III. The epithelial height of bronchiole decreased from group-II to group-III in left apical and right diaphragmatic lobes. While, the height of nucleus of bronchiole decreased significantly from group-II to group-III in left apical, left cardiac and left diaphragmatic lobes. The epithelial height of bronchi decreased significantly from group-II to group-III in apical and accessory lobes of right lung. However, the nucleus height of bronchi decreased significantly from group-II to group-III in right apical and right diaphragmatic lobes.

\section{Introduction}

According to $19^{\text {th }}$ livestock census (2012) the total sheep population of Himachal Pradesh is $8,04,334$ and Gaddi sheep comprises 70 percent of the total sheep population. Gaddi sheep is a medium sized breed and is one among forty two well-defined sheep breeds of India, mainly distributed in Kangra, Shimla, Chamba, Kinnour and Kullu districts of Himachal Pradesh. The main objective of the study was to establish histogenesis and organogenesis of lung in prenatal period of Gaddi sheep.

Review of literature reveals that the studies on micrometrical parameters of bronchiole and bronchi are very little in Gaddi sheep. Keeping this fact in mind present investigation was carried out to elucidate the micrometrical details of bronchiole and bronchi in Gaddi sheep lung. 


\section{Materials and Methods}

\section{Collection and estimation of age of Gaddi sheep fetuses}

Eighteen Gaddi sheep fetuses were collected from the slaughter houses in and around Palampur region and were then divided into three groups based on their estimated ages viz.- Group-I (below 50 days), Group-II (between 50-100 days), Group-III (above 100 days of age) containing 6 number of fetuses in each group. The age of the fetus was obtained by the formula given by Singh et al., (1979),

$\mathrm{W}^{1 / 3}=0.096(\mathrm{t}-30)$

Where, 'W' is body weight of fetus in grams, ' $t$ ' is age of fetus in days.

\section{Collection and histological processing of tissue for micrometrical study}

The tissue pieces were collected from apical lobe (at the middle point of cranial and caudal part), cardiac lobe (at the middle point), diaphragmatic lobe (cranially at $0.5 \mathrm{~cm}$ behind the interlobular fissure between the cardiac and diaphragmatic lobes) in both right and left lungs. Whereas, in accessory lobe which is present only in the right lung, the tissue was collected at the middle point of the formalin fixed lung lobe of the sheep fetuses. These tissues were processed for paraffin block preparation by alcohol- benzene schedule (Luna, 1968). Tissue sections of 5-6 $\mu \mathrm{m}$ were stained with Haematoxylin and Eosin.

The parameters which were measured include diameter of bronchiole, diameter of bronchi, epithelium height of bronchiole, nucleus height of the epithelium of bronchiole, epithelium height of bronchi and nucleus height of the epithelium of bronchi. The lungs of group-I of sheep fetuses were embedded as a whole due to very small size of the lobes. So the readings of group-I were taken as a whole.
The comparison is done between various lobes of group-II and group-III. Bronchi are absent in group-I as it depicts tubular stage of lung development which indicates mainly presence of tubules scattered in the loose mesenchymal tissue. Contrary to which bronchi are present in group-II and group-III which depicts the higher stages of lung development. So, in the present study the first comparison is done between the overall values of various parameters between the three groups. However, the second comparison is made between different parameters of bronchiole and bronchi which are present in group-II and group-III and various lobes of both right and left lungs.

The mean values of all the micrometrical parameters were subjected to statistical analysis for comparison between the different lobes of lungs using one way ANOVA and T test (SAS Statistics-9.2). A probability of $\mathrm{p}<0.05$ was considered as statistically significant.

\section{Results and Discussion}

\section{Diameter of bronchiole}

In the sheep fetuses of group-I the overall diameter of bronchiole was recorded as $168.25 \pm 13.02 \mu \mathrm{m}$. While, in group-II and group-III the overall diameter was recorded as $196.80 \pm 13.68 \mu \mathrm{m}$ and $203.57 \pm 7.66 \mu \mathrm{m}$. The diameter of bronchiole in various lobes of both right and left lung of group II and group III has been listed in Table 1 . The diameter of bronchiole was significantly highest in the left diaphragmatic lobe in group II.

The overall diameter of bronchiole increased from group-I to group-III. The diameter of bronchiole increased significantly in left apical, right cardiac and right accessory lobe whereas it decreased significantly in left diaphragmatic lobe from group-II to groupIII. 


\section{Diameter of bronchi}

The overall diameter of bronchi was $389.09 \pm$ $20.57 \mu \mathrm{m}$ in group-II which decreased significantly to $334.30 \pm 16.47 \mu \mathrm{m}$ in groupIII. The diameter of bronchi in various lobes of group II and group III of both right and left lungs has been recorded in Table 1. The diameter of bronchi decreased significantly in right apical, left apical and left cardiac lobe but it increased significantly in right cardiac and left diaphragmatic lobe from group-II to group-III.

\section{Epithelium height of bronchiole}

In the Gaddi sheep fetuses of group-I the height of epithelium of bronchiole was recorded as $39.40 \pm 2.33 \mu \mathrm{m}$ which decreased significantly to $9.67 \pm 0.26 \mu \mathrm{m}$ and $8.35 \pm$ $0.15 \mu \mathrm{m}$ in group-II and group-III respectively. In group-II, the epithelium height of bronchiole was significantly higher in right diaphragmatic lobe as compared to right apical and right cardiac lobe of lung. Whereas, in rest of the lobes epithelial height of bronchiole did not vary significantly (Table 2). While, in group-III the epithelium height of bronchiole was highest in left diaphragmatic lobe and lowest in left apical lobe. However, there was no significant variation in the epithelial height within various lobes of left and right lung (Table 2).

The epithelial height of bronchiole decreased from group-II to group-III in left apical and right diaphragmatic lobes. Between group-II and III a non-significant decrease was observed in epithelium height in the rest of the lobes of right and left lung respectively.

\section{Nucleus height of epithelium of bronchiole}

In the Gaddi sheep fetuses of group-I the overall height of nucleus of bronchiole was $8.51 \pm 0.32 \mu \mathrm{m}$ which decreased to $5.84 \pm 0.11$ $\mu \mathrm{m}$ and $5.39 \pm 0.07 \mu \mathrm{m}$ in group-II and III respectively. In group-II, the diaphragmatic lobe of left lung had significantly higher nuclear height as compare to apical lobe of right lung, which had lowest nuclear height of epithelium of bronchiole among all the lobes of lung. Whereas, in rest of the lobes epithelial height of bronchiole did not vary significantly (Table 2). In group-III there was no significant difference within the lobes of left and right lung. In general, the nucleus height of bronchiole decreased with increase in gestational age except for right apical lobe in the present study. The height of nucleus of bronchiole decreased significantly from group-II to group-III in left apical, left cardiac and left diaphragmatic lobes (Table 2).

\section{Epithelium height of bronchi}

The overall height of epithelium of bronchi of group-II was recorded as $12.98 \pm 0.64 \mu \mathrm{m}$, which decreased to $10.94 \pm 0.33 \mu \mathrm{m}$ in groupIII in the Gaddi sheep fetuses. In Group-II, the epithelial height in right apical lobe was significantly higher than all the lobes of lungs followed by left diaphragmatic lobe. Left apical, left cardiac and accessory lobes did not varied significantly from left and right diaphragmatic lobes. Thereafter, the epithelial height reduced significantly in bronchi present in cardiac lobe of the right lung (Table 2). While in group-III, the epithelial height of bronchi epithelium was significantly higher in cardiac lobe of left lung as compared to that of apical, diaphragmatic and accessory lobes of right lung (Table 2).

The epithelial height of bronchi decreased significantly from group-II to group-III in apical and accessory lobes of right lung. In rest of the lobes change was non-significant.

\section{Nucleus height of epithelium of bronchi}

In the Gaddi sheep fetuses of group-II the overall height of nucleus of bronchi was recorded as $12.98 \pm 0.64 \mu \mathrm{m}$ which reduced to $10.94 \pm 0.33 \mu \mathrm{m}$ in group-III. In group-II, 
the height of nucleus was recorded to be significantly highest in right apical lobe as compare to that of left apical \& right cardiac lobe (Table 2). While the other lobes of right and left lung had intermediate values of nuclear height which did not vary significantly. While in group-III, there was no significant difference in the values of nucleus height within the various lobes of right and left lung respectively (Table 2 ).

The nucleus height of bronchi decreased significantly from group-II to group-III in right apical and right diaphragmatic lobes. The nucleus height of rest of the lobes decreased non- significantly with increase in gestational age except that of right cardiac lobe.

The diameter of bronchiole increased significantly in left apical, right cardiac and right accessory lobe whereas it decreased significantly in left diaphragmatic lobe from group-II to group-III. The diameter of bronchi decreased significantly in right apical, left apical and left cardiac lobe but it increased significantly in right cardiac and left diaphragmatic lobe from group-II to groupIII.

Table.1 Diameter of bronchiole and bronchi of different lobes

\begin{tabular}{|c|c|c|c|c|}
\hline \multirow[b]{2}{*}{ LOBES } & \multicolumn{2}{|c|}{ Diameter of bronchiole } & \multicolumn{2}{|c|}{ Diameter of bronchi } \\
\hline & Group II & Group-III & Group II & Group-III \\
\hline \multicolumn{5}{|l|}{ Apical lobe } \\
\hline Right lung & $\begin{array}{l}156.98^{\mathrm{B}} \\
\pm 33.41 \\
(114.36-323.39)\end{array}$ & $\begin{array}{l}185.48^{\mathrm{AB}} \\
\pm 19.68 \\
(113.44-263.74)\end{array}$ & $\begin{array}{l}598.31^{\mathrm{Aa}} \\
\pm 5.88 \\
(574.94-613.52)\end{array}$ & $\begin{array}{l}265.39^{\mathrm{BCb}} \\
\pm 14.42 \\
(217.21-300.66)\end{array}$ \\
\hline Left lung & $\begin{array}{l}152.85^{\mathrm{Ba}} \\
\pm 11.13 \\
(112.59-181.21)\end{array}$ & $\begin{array}{l}201.09^{\mathrm{ABb}} \\
\pm 17.91 \\
(170.92-288.48)\end{array}$ & $\begin{array}{l}403.41^{\mathrm{Ca}} \\
\pm 1.23 \\
(398.69-407.35)\end{array}$ & $\begin{array}{l}311.12^{\mathrm{BCb}} \\
\pm 22.84 \\
(254.29-369.75)\end{array}$ \\
\hline \multicolumn{5}{|c|}{ Cardiac lobe } \\
\hline Right lung & $\begin{array}{l}130.38^{\mathrm{Ba}} \\
\pm 10.99 \\
(96.19-156.91)\end{array}$ & $\begin{array}{l}204.09^{\mathrm{ABb}} \\
\pm 6.26 \\
(193.43-232.68)\end{array}$ & $\begin{array}{l}211.23^{\mathrm{Ea}} \\
\pm 15.01 \\
(177.61-244.81)\end{array}$ & $\begin{array}{l}333.11^{\mathrm{BCb}} \\
\pm 28.12 \\
(229.78-391.84)\end{array}$ \\
\hline Left lung & $\begin{array}{l}231.69^{\mathrm{AB}} \\
\pm 52.65 \\
(129.99-452.41)\end{array}$ & $\begin{array}{l}161.81^{\mathrm{B}} \\
\pm 15.75 \\
(98.42-193.83)\end{array}$ & $\begin{array}{l}513.33^{\mathrm{Ba}} \\
\pm 0.08 \\
(512.98-513.55)\end{array}$ & $\begin{array}{l}347.18^{\mathrm{Bb}} \\
\pm 28.17 \\
(259.69-414.81)\end{array}$ \\
\hline \multicolumn{5}{|c|}{ Diaphragmatic lobe } \\
\hline Right lung & $\begin{array}{l}239.58^{\mathrm{AB}} \\
\pm 28.47 \\
(171.80-347.41)\end{array}$ & $\begin{array}{l}209.10^{\mathrm{AB}} \\
\pm 10.31 \\
(161.15-231.68)\end{array}$ & $\begin{array}{l}294.26^{\mathrm{D}} \\
\pm 40.46 \\
(199.82-471.51)\end{array}$ & $\begin{array}{l}221.98^{\mathrm{C}} \\
\pm 21.06 \\
(168.55-312.07)\end{array}$ \\
\hline Left lung & $\begin{array}{l}312.62^{\mathrm{Aa}} \\
\pm 19.73 \\
(228.11-343.73)\end{array}$ & $\begin{array}{l}203.29^{\mathrm{ABb}} \\
\pm 19.01 \\
(138.41-278.78)\end{array}$ & $\begin{array}{l}414.12^{\mathrm{Ca}} \\
\pm 15.52 \\
(364.73-439.56)\end{array}$ & $\begin{array}{l}514.21^{\mathrm{Ab}} \\
\pm 0.81 \\
(510.45-516.04)\end{array}$ \\
\hline \multicolumn{5}{|c|}{ Accessory lobe } \\
\hline Right lung & $\begin{array}{l}153.53^{\mathrm{Ba}} \\
\pm 12.81 \\
(94.25-175.46)\end{array}$ & $\begin{array}{l}260.13^{\mathrm{Ab}} \\
\pm 28.99 \\
(183.07-359.18)\end{array}$ & $\begin{array}{l}289.03^{\mathrm{D}} \\
\pm 1.09 \\
(285.58-291.51)\end{array}$ & $\begin{array}{l}347.12^{\mathrm{B}} \\
\pm 51.89 \\
(274.81-588.79) \\
\end{array}$ \\
\hline
\end{tabular}

Values having different superscripts in each row $(\mathrm{a}, \mathrm{b})$ and column $(\mathrm{A}, \mathrm{B}, \mathrm{C}, \mathrm{D}, \mathrm{E})$ differ significantly $(\mathrm{P}<0.05)$

Values within parenthesis denote the range. 
Table.2 Epithelial and nucleus height of bronchiole and bronchi

\begin{tabular}{|c|c|c|c|c|c|c|c|c|}
\hline \multirow[b]{2}{*}{ LOBES } & \multicolumn{2}{|c|}{$\begin{array}{l}\text { Epithelium height } \\
\text { of bronchiole }\end{array}$} & \multicolumn{2}{|c|}{$\begin{array}{l}\text { Nucleus height of } \\
\text { bronchiole }\end{array}$} & \multicolumn{2}{|c|}{$\begin{array}{l}\text { Epithelium height of } \\
\text { bronchi }\end{array}$} & \multicolumn{2}{|c|}{$\begin{array}{l}\text { Nucleus height of } \\
\text { bronchi }\end{array}$} \\
\hline & Group II & $\begin{array}{l}\text { Group } \\
\text { III }\end{array}$ & $\begin{array}{l}\text { Group } \\
\text { II }\end{array}$ & $\begin{array}{l}\text { Group } \\
\text { III }\end{array}$ & $\begin{array}{l}\text { Group } \\
\text { II }\end{array}$ & $\begin{array}{l}\text { Group } \\
\text { III }\end{array}$ & $\begin{array}{l}\text { Group } \\
\text { II }\end{array}$ & $\begin{array}{l}\text { Group } \\
\text { III }\end{array}$ \\
\hline \multicolumn{9}{|c|}{ Apical lobe } \\
\hline $\begin{array}{l}\text { Right } \\
\text { lung }\end{array}$ & $\begin{array}{l}8.50^{\mathrm{B}} \\
\pm 0.34 \\
(7.79- \\
10.11)\end{array}$ & $\begin{array}{l}7.89 \\
\pm 0.39 \\
(6.45- \\
9.09)\end{array}$ & $\begin{array}{l}5.14^{\mathrm{B}} \\
\pm 0.21 \\
(4.34- \\
5.68)\end{array}$ & $\begin{array}{l}5.36 \\
\pm 0.25 \\
(4.67- \\
6.31)\end{array}$ & $\begin{array}{l}22.62^{\mathrm{Aa}} \\
\pm 0.19 \\
(21.98- \\
23.12)\end{array}$ & $\begin{array}{l}9.38^{\mathrm{Cb}} \\
\pm 0.38 \\
(8.23- \\
10.87)\end{array}$ & $\begin{array}{l}6.95^{\mathrm{Aa}} \\
\pm 0.05 \\
(6.75- \\
7.10)\end{array}$ & $\begin{array}{l}5.92^{\mathrm{b}} \\
\pm 0.13 \\
(5.68- \\
6.52)\end{array}$ \\
\hline $\begin{array}{l}\text { Left } \\
\text { lung }\end{array}$ & $\begin{array}{l}9.07^{\mathrm{ABa}} \\
\pm 0.33 \\
(7.72- \\
9.70)\end{array}$ & $\begin{array}{l}7.81^{\mathrm{b}} \\
\pm 0.29 \\
(7.07- \\
8.93)\end{array}$ & $\begin{array}{l}6.23^{\mathrm{ABa}} \\
\pm 0.24 \\
(5.22- \\
6.88)\end{array}$ & $\begin{array}{l}5.35^{\mathrm{b}} \\
\pm 0.12 \\
(4.92- \\
5.65)\end{array}$ & $\begin{array}{l}11.45^{\mathrm{BC}} \\
\pm 0.22 \\
(10.83- \\
12.11)\end{array}$ & $\begin{array}{l}10.88^{\mathrm{ABC}} \\
\pm 0.57 \\
(9.07- \\
12.89)\end{array}$ & $\begin{array}{l}5.93^{\mathrm{B}} \\
\pm 0.23 \\
(5.37- \\
6.97)\end{array}$ & $\begin{array}{l}5.82 \\
\pm 0.21 \\
(5.26- \\
6.54)\end{array}$ \\
\hline \multicolumn{9}{|c|}{ Cardiac lobe } \\
\hline $\begin{array}{l}\text { Right } \\
\text { lung }\end{array}$ & $\begin{array}{l}8.55^{\mathrm{B}} \\
\pm 0.14 \\
(8.16- \\
9.11)\end{array}$ & $\begin{array}{l}8.40 \\
\pm 0.28 \\
(7.24- \\
9.37)\end{array}$ & $\begin{array}{l}5.83^{\mathrm{AB}} \\
\pm 0.32 \\
(4.95- \\
6.85)\end{array}$ & $\begin{array}{l}5.56 \\
\pm 0.25 \\
(4.77- \\
6.22) \\
\end{array}$ & $\begin{array}{l}{ }^{\mathrm{D}} 9.36 \\
\pm 0.15 \\
(8.91-9.65)\end{array}$ & $\begin{array}{l}10.64^{\mathrm{BC}} \\
\pm 0.66 \\
(8.61- \\
12.14)\end{array}$ & $\begin{array}{l}5.93^{\mathrm{B}} \\
\pm 0.14 \\
(5.59- \\
6.61) \\
\end{array}$ & $\begin{array}{l}6.99 \\
\pm 0.66 \\
(5.10- \\
8.90)\end{array}$ \\
\hline $\begin{array}{l}\text { Left } \\
\text { lung }\end{array}$ & $\begin{array}{l}9.55^{\mathrm{AB}} \\
\pm 0.37 \\
(8.69- \\
11.30)\end{array}$ & $\begin{array}{l}8.69 \\
\pm 0.41 \\
(6.90- \\
9.57)\end{array}$ & $\begin{array}{l}6.15^{\mathrm{ABa}} \\
\pm 0.11 \\
(5.87- \\
6.58)\end{array}$ & $\begin{array}{l}5.36^{\mathrm{b}} \\
\pm 0.15 \\
(5.01- \\
5.93)\end{array}$ & $\begin{array}{l}11.79^{\mathrm{BC}} \pm \\
0.09 \\
(11.45- \\
12.01)\end{array}$ & $\begin{array}{l}13.55^{\mathrm{A}} \\
\pm 0.94 \\
(11.21- \\
17.40)\end{array}$ & $\begin{array}{l}6.29^{\mathrm{AB}} \\
\pm 0.19 \\
(5.66- \\
6.87)\end{array}$ & $\begin{array}{l}6.12 \\
\pm 0.35 \\
(5.30- \\
7.77)\end{array}$ \\
\hline \multicolumn{9}{|c|}{ Diaphragmatic lobe } \\
\hline $\begin{array}{l}\text { Right } \\
\text { lung }\end{array}$ & $\begin{array}{l}11.31^{\mathrm{Aa}} \\
\pm 0.76 \\
(9.20- \\
14.08)\end{array}$ & $\begin{array}{l}8.18^{b} \\
\pm 0.35 \\
(7.08- \\
9.42)\end{array}$ & $\begin{array}{l}5.53^{\mathrm{AB}} \\
\pm 0.34 \\
(4.34- \\
6.54)\end{array}$ & $\begin{array}{l}4.86 \\
\pm 0.16 \\
(4.32- \\
5.36)\end{array}$ & $\begin{array}{l}11.02^{\mathrm{C}} \\
\pm 0.61 \\
(8.91- \\
12.45)\end{array}$ & $\begin{array}{l}9.04^{\mathrm{C}} \\
\pm 0.68 \\
(7.00- \\
11.54)\end{array}$ & $\begin{array}{l}6.83^{\mathrm{ABa}} \\
\pm 0.37 \\
(5.66- \\
7.91)\end{array}$ & $\begin{array}{l}5.61^{\mathrm{b}} \\
\pm 0.18 \\
(4.97- \\
6.31)\end{array}$ \\
\hline $\begin{array}{l}\text { Left } \\
\text { lung }\end{array}$ & $\begin{array}{l}10.96^{\mathrm{AB}} \\
\pm 1.08 \\
(8.52- \\
15.78)\end{array}$ & $\begin{array}{l}8.86 \quad \pm \\
0.51 \\
(7.86- \\
10.47)\end{array}$ & $\begin{array}{l}6.34^{\mathrm{Aa}} \\
\pm 0.13 \\
(5.91- \\
6.74)\end{array}$ & $\begin{array}{l}5.64^{\mathrm{b}} \\
\pm 0.16 \\
(5.20- \\
6.15)\end{array}$ & $\begin{array}{l}12.71^{\mathrm{B}} \\
\pm 0.54 \\
(10.92- \\
14.82)\end{array}$ & $\begin{array}{l}13.07^{\mathrm{AB}} \\
\pm 0.19 \\
(12.12- \\
13.35)\end{array}$ & $\begin{array}{l}6.57^{\mathrm{AB}} \\
\pm 0.11 \\
(6.32- \\
6.90)\end{array}$ & $\begin{array}{l}6.16 \\
\pm 0.19 \\
(5.45- \\
6.77)\end{array}$ \\
\hline \multicolumn{9}{|c|}{ Accessory lobe } \\
\hline $\begin{array}{l}\text { Right } \\
\text { lung }\end{array}$ & $\begin{array}{l}9.74^{\mathrm{AB}} \\
\pm 0.39 \\
(8.88- \\
11.52)\end{array}$ & $\begin{array}{l}8.64 \\
\pm 0.45 \\
(7.41- \\
9.91)\end{array}$ & $\begin{array}{l}5.70^{\mathrm{AB}} \\
\pm 0.32 \\
(4.80- \\
7.11)\end{array}$ & $\begin{array}{l}5.65 \\
\pm 0.12 \\
(5.36- \\
6.14)\end{array}$ & $\begin{array}{l}11.88{ }^{\mathrm{BCa}_{ \pm}} \\
0.19 \\
(11.34- \\
12.47)\end{array}$ & $\begin{array}{l}10.03^{\mathrm{Cb}} \\
\pm 0.68 \\
(8.47- \\
12.00)\end{array}$ & $\begin{array}{l}6.21^{\mathrm{AB}} \\
\pm 0.24 \\
(5.30- \\
6.90)\end{array}$ & $\begin{array}{l}5.97 \\
\pm 0.29 \\
(5.23- \\
6.95)\end{array}$ \\
\hline
\end{tabular}

Values having different superscripts in each row $(a, b)$ and column $(A, B, C)$ differ significantly $(P<0.05)$.

Values within parenthesis denote the range.

Sohi et al., (2006) reported in buffalo fetuses bronchiolar diameter decreased with increase in CRL. Castleman and Lay (1990) stated that the mean bronchiolar cross-sectional area increased significantly with age in calves. Similar observations were found by Bhattacharya (1994) in goat fetuses. The epithelium height of bronchiole was significantly higher in right diaphragmatic lobe as compared to right apical and right cardiac lobe of lung in Gaddi sheep fetuses of 50-100 days of gestation. In the present study it was observed that with the advancement of gestational age the epithelial height of 
bronchiole decreased as reported earlier by Sohi et al., (2006) in fetuses of Indian buffalo. The epithelial height of bronchi decreased significantly from group-II to group-III in apical and accessory lobes of right lung. In rest of the lobes change was non-significant. Sohi et al., (2006) had also reported that the epithelial height decreased with increase in Crown Rump Length in the lungs of prenatal Indian buffalo.

The epithelial height of bronchiole decreased with the advancement of gestational age. While, the nucleus height of bronchiole decreased with increase in gestational age except for right apical lobe in the current study. The epithelial height of bronchi decreased significantly from group-II to group-III in apical and accessory lobes of right lung. However, the nucleus height of bronchi decreased significantly from group-II to group-III in right apical and right diaphragmatic lobes.

\section{Acknowledgements}

To the Department of Veterinary Anatomy, DGCN COVAS, CSKHPKV, Palampur, Himachal Pradesh, India.

\section{References}

Bhattacharya, R.N. 1994. Postnatal development of the lung (0-30 days) in Assam local goat (Capra hircus). M. V. Sc. Thesis, Assam Agricultural University, Assam, India.

Castleman, W.L., and Lay J.C. 1990. Morphometric and ultrastructural study of postnatal lung growth and development in calves. American journal of veterinary research. 51(5):789-95.

Livestock census. 2012. All India report. Ministry of Agriculture, Department of Animal Husbandry, Dairying and Fisheries, Krishi Bhawan, New Delhi.

Luna, L.G. 1968. Manual of histological staining methods of Armed forces institute of Pathology. $3^{\text {rd }}$ Edn. New York: McGraw-Hill. Pp. 153-173.

Sahi, B.S., Singh, O. and Madhok, A.K. 2006. Biometry and histomorphometry, of prenatal lung'in Indian buffalo. Indian Journal of Animal Sciences. 1:76(12).

Singh, Y., Sharma, D.N. and Dhingra, L.D. 1979. Morphogenesis of the testis in goat [India]. Indian Journal of Animal Sciences. 49: 925-931.

\section{How to cite this article:}

Brij Vanita, Rajesh Rajput, Virender Pathak, Varun Sankhyan and Ankaj Thakur. 2019. Micrometrical Studies of Bronchi and Bronchiole in Prenatal Gaddi (Breed) Sheep Lung. Int.J.Curr.Microbiol.App.Sci. 8(04): 1860-1865. doi: https://doi.org/10.20546/ijcmas.2019.804.217 